\title{
Antibody to hepatitis B antigen in haemophiliacs and their household contacts
}

\author{
C. J. BURRELL, A. C. PARKER, D. M. RAMSAY, AND ELAINE PROUDFOOT
}

From the Department of Bacteriology, Edinburgh University Medical School, Edinburgh, and the Department of Haematology, Royal Infirmary, Edinburgh

SYNOPSIS The prevalence of antibody to hepatitis B antigen, detectable by radioimmunoassay, was found to be no higher among 58 long-term household contacts of multiply transfused haemophiliacs than among 100 randomly chosen blood donors. This suggested that such contacts do not have greater exposure to serum hepatitis virus than that occurring through natural means. Among those persons possessing antibody, the multiply transfused haemophiliacs showed a marked tendency for higher antibody titres than their contacts, implying differences in pathogenesis between infection acquired through multiple transfusion and infection acquired naturally.

The presence of antibody to hepatitis $B$ antigen (HB Ag) is considered on epidemiological grounds to be an indication of previous infection with serum hepatitis virus. Using the sensitive techniques of passive haemagglutination or radioimmunoassay for detection of antibody, recent serological surveys have suggested that subclinical infection may be a common event. It has been possible to relate this to known risk factors such as multiple transfusion with blood or blood products and contact with renal dialysis units or institutions for the mentally retarded (Lander, Alter, and Purcell, 1971; Szmuness, Prince, Etling, and Pick, 1972; Pattison, Maynard, Berquist, and Webster, 1973). As a corollary to this, means of transmission of the disease other than skin penetration are being increasingly implicated, including close physical contact (Heathcote and Sherlock, 1973; Fulford, Dane, Catterall, Woof, and Denning, 1973) and, perhaps exceptionally, aerosol spread (Almeida, Kulatilake, Mackay, Shackman, and Chisholm, 1971). To extend observations to another group possibly at risk, we have examined the long-term household contacts of haemophiliacs attending the Edinburgh Haemophilia Reference Centre. Evidence is now presented that such contacts do not have a higher prevalence of antibody to $\mathrm{HB} \mathrm{Ag}$ than that occurring in a control population at large.

\section{Methods and Results}

Haemophiliacs were classified as severely affected Received for publication 3 January 1974. (plasma factor VIII or IX $<1 \%$ ) and others (plasma factor VIII or IX $>1 \%$ ). Those in the severely affected group had received transfusions on at least nine occasions before the study, in most cases considerably more, while the others had mainly required replacement for elective procedures and their transfusion rates were comparatively low. Regular blood donor screening for $\mathrm{HB} \mathrm{Ag}$ by countercurrent immunoelectrophoresis (CIEOP, Prince and Burke, 1970) began in Edinburgh in February 1971. Almost all the transfused haemophiliacs in this study had received untested blood or blood products before that date. The household contacts of each haemophiliac were classified as wife (genetically unrelated), or mother, or other genetically related contact.

Only one of the 46 haemophiliacs and none of the 58 contacts were positive for HB Ag by the CIEOP test; this haemophiliac was a known long-term carrier of $\mathrm{HB} \mathrm{Ag}$ with persistently elevated serum glutamic-oxaloacetic transaminase levels but no

\begin{tabular}{lcl}
\hline & Positive & Total \\
\hline Total haemophiliacs & $17(36.9 \%)$ & 46 \\
Severely affected haemophiliacs & $15(55.5 \%)$ & 27 \\
Other haemophiliacs & $2(10.5 \%)$ & 19 \\
Total contacts & $10(17.2 \%)$ & 58 \\
Wives & $0(0)$ & 9 \\
Mothers & $4(19.0 \%)$ & 21 \\
Other contacts & $6(21.4 \%)$ & 28 \\
Blood donors & $16(16 \%)$ & 100 \\
\hline
\end{tabular}

Table I Prevalence of antibody to $\mathrm{HB} \mathrm{Ag}$, detectable by radioimmunoassay among the various groups studied 
Table II Distribution of titres of antibody to $\mathrm{HB}$ Ag among the haemophiliacs and their contacts

other evidence of liver dysfunction. Three of the haemophiliacs and five of the contacts gave a past history of jaundice.

In order to obtain a more sensitive indication of the spread of infection, the groups were also tested for antibody to HB Ag. Sera were taken from each haemophiliac and his household contacts at the same time when possible, and examined for antibody to $\mathrm{HB} \mathrm{Ag}$ by a double antibody radioimmunoassay (Lander et al, 1971; Hollinger, Vorndam, and Dreesman, 1971). Sera diluted 1 in 20 in phosphatebuffered saline containing $0.5 \%$ bovine serum albumin were incubated for two days at $4^{\circ}$ in the presence of ${ }^{125} \mathrm{I}$ labelled $\mathrm{HB} \mathrm{Ag}$ (approximately $3 \mathrm{ng} \mathrm{HB}$ Ag protein), and for a further $16 \mathrm{hr}$ at $4^{\circ}$ after the addition of rabbit antihuman IgG. The remaining steps in the procedure were as described for the radioimmunoassay of HB Ag (Burrell, Proudfoot, Keen, and Marmion, 1973). Labelled HB Ag subtype 'ay' was used, since preliminary results had indicated that antibodies to this subtype were commoner in Edinburgh than antibodies to subtype 'ad'. Test sera precipitating greater than $15 \%$ labelled $\mathrm{HB} \mathrm{Ag}$ were considered positive for antibody; this figure lay well outside 3 standard deviations from the mean of six negative control sera, which precipitated from 7 to $12 \%$ with different preparations of labelled HB Ag.

The prevalence of antibody to $\mathrm{HB} \mathrm{Ag}$ among the groups studied in comparison with 100 randomly chosen volunteer blood donors is shown in table $\mathrm{I}$. A significantly greater prevalence of antibody was found in the total haemophiliacs compared to both the total household contacts $(0.01>P>0.001)$ and the blood donors $(P<0.001)$, while no difference was seen between total household contacts and random blood donors $(P>0.5)$. In particular wives did not appear to be at special risk, although the numbers in this group were small. The prevalence of antibody among the haemophiliacs was greatest in that group receiving regular transfusion. The antibody-positive sera were then titrated and grouped according to their titres (table II); the distribution of antibody titres among the haemophiliacs was markedly slanted towards high titres, while low titres were commoner among their contacts.

\section{Discussion}

Our findings confirm the report of Lander et al $\vec{\omega}$ (1971) showing a higher prevalence of antibody to HB Ag among multiply transfused persons than among blood donors. On the other hand, long- $v$ term contacts of these patients did not have a $\rightarrow$ significantly higher antibody prevalence than vol- $\mathrm{N}_{\mathrm{W}}$ untary blood donors, suggesting that household contact with multiply transfused persons does not lead to a higher rate of subclinical serum hepatitis infection than that occurring endemically in the general population.

The distribution of antibody titres is of particular $\vec{\theta}$ interest. High titre antibodies, detectable by CIEOP, $\nsubseteq$ have often been noted among multiply transfused $O$ patients. Our results demonstrate a marked tendency for high titres in this group compared with patients acquiring infection through natural means when low titre antibodies appear the most usual $\frac{\mathrm{Q}}{\circ}$ occurrence. This may be due to repeated subclinical $\underset{\vec{F}}{\overrightarrow{7}}$ infections with serum hepatitis or to repeated $\frac{0}{3}$ active immunization with non-replicating antigenic material. Further knowledge of the pathogenesis of serum hepatitis should help to clarify this point.

We wish to thank Professor B. P. Marmion, Department of Bacteriology, and Dr S. H. Davies, Department of Haematology, for their helpful $\frac{0}{0}$ guidance in this work and criticism of the manuscript. We are grateful to Mr R. Hopkins, Blood Transfusion Service, Edinburgh, for collaboration. $>$ This work was supported in part by a grant from the Scottish Home and Health Department.

\section{References}

Almeida., J. D., Kulatilake, A. E., Mackay, D. H., Shackman, R., N Chisholm, G. D., MacGregor, A. B., O'Donoghue, E. P. N., $\omega$ and Waterson, A. P. (1971). Possible airborne spread of serum-hepatitis virus within a haemodialysis unit. Lancet, 2, 849-850.

Burrell, C. J., Proudfoot, E., Keen, G. A., and Marmion, B. P. (1973). $\bar{\varnothing}$ Carbohydrates in Hepatitis B antigen. Nature [new Biol.], $\stackrel{\mathcal{P}}{\longrightarrow}$ 243, 260-262.

Fulford, K. W. M., Dane, D. S., Catterall, R. D., Woof, R., and $\square$ Denning, J. V. (1973). Australia antigen and antibody among patients attending a clinic for sexually transmitted diseases. Lancet, 1, 1470-1473.

Heathcote, J., and Sherlock, S. (1973). Spread of acute type-B hepatitis in London. Lancet, 1, 1468-1470.

Hollinger, F. B., Vorndam, V., and Dreesman, G. R. (1971). Assay of Australia antigen and antibody employing double-antibody $O$ 
and solid-phase radioimmunoassay techniques and comparison with the passive hemagglutination methods. J. Immunol., 107, 1099-1111.

Lander, J. J., Alter, H. J., and Purcell, R. H. (1971). Frequency of antibody to hepatitis-associated antigen as measured by a new radioimmunoassay technique. J. Immunol., 106, 1166-1171.

Pattison, C. P., Maynard, J. E., Berquist, K. R., Webster, H. M. 1973). Serological and epidemiological studies of hepatitis
B in haemodialysis units, Lancet, 2, 172-174.

Prince, A. M., and Burke, K. (1970). Serum hepatitis antigen (SH): rapid detection by high voltage immunoelectroosmophoresis. Science, 169, 593-595.

Szmuness, W., Prince, A. M., Etling, G. F., and Pick, R. (1972). Development and distribution of hemagglutinating antibody against the hepatitis $B$ antigen in institutionalized populations. J. infect. Dis., 126, 498-506.

\section{Reports and Bulletins prepared by the Association of Clinical Biochemists}

The following reports and bulletins are published by the Association of Clinical Biochemists. They may be obtained from Dr D. H. Orrell, Department of Pathology, Royal Infirmary, Chorley New Road, Bolton BL1 4QS. Overseas readers should remit by British Postal or Money Order.

SCIENTIFIC REPORTS (price $£ 1 \cdot 00 / \$ 2.00$ each)

3 Automatic Dispensing Pipettes: an assessment of 35 commercial instruments September 1967 P. M. G. BROUGHTON, A. H. GOWENLOCK, G. M. WIDDOWSON, and K. A. AHLQUIST

4 An Evaluation of five Commercial Flame Photometers suitable for the Simultaneous Determination of Sodium and Potassium March 1970 P. M. G. BROUGHTON and J. B. DAWSON

SCIENTIFIC REVIEWS (price $£ 1 \cdot 00 / \$ 2.00$ each)

1 The Assessment of Thyroid Function March 1971 F. V. FLYNN and J. R. HOBBS

2 Renal Function Tests Suitable for Clinical Practice January 1972 F. L. MITCHELl, N. VEALL, and R. W. E. WATTS

TECHNICAL BULLETINS (price $£ 1 \cdot 00 / \$ 2.00$ each)

9 Determination of Urea by AutoAnalyzer November 1966 RUTH M. HASLAM

11 Determination of Serum Albumin by AutoAnalyzer using Bromocresol Green October 1967 B. E. NORTHAM and G. M. WIDDOwsoN

13 An Assessment of the Technicion Type II Sampler Unit March 1968 B. C. GRAY and G. K. MCGOWAN

14 Atomic Absorption Spectroscopy: an outline of its principles and a guide to the selection of instruments May 1968 J. B. DAWSON and P. M. G. BROUGHTON

15 A Guide to Automatic Pipettes (2nd edition) June 1968 P. M. G. BROUGHTON

16 A Guide to Automation in Clinical Chemistry May 1969 P. M. G. BROUGHTON

17 Flame Photometers: a comparative list of 17 instruments readily available in Britain August 1969 P. WILDING
19 Spectrophotometers: a comparative list of low-priced instruments readily available in Britain May 1970 C. E. WILDE and P. SEWELL

20 Quantities and Units in Clinical Biochemistry June 1970 P. M. G. BROUGHTON

21 Filter Fluorimeters: A comparative list of 18 instruments September 1970 H. BRAUNSBERG and $s$. $s$. BROWN

22 Bilirubin Standards and the Determination of Bilirubin by Manual and Technicon AutoAnalyzer Methods January 1971 BARBARA BILLING, RUTH HASLAM, and N. WALD

23 Interchangeable Cells for Spectrophotometers and Fluorimeters September 1971 S. S. BROWN and A. H. GOWENLOCK

24 Simple Tests to Detect Poisons March 1972 B. w. MEADE et $a l$.

\section{Blood Gas Analysers May 1972 K. DIXoN}

26 Kits for Enzyme Activity Determination September 1972 s. B. ROSALKI and D. TARLOW

27 Assessment of Pumps Suitable for Incerporation into Existing Continuous Flow Analytical Systems November 1972 A. FLECK $e t$ al.

28 Routine Clinical Measurements of Transferrin in Human Serum September 1973 K. DIXON

29 Control Materials for Clinical Biochemistry (5th edition) September 1973 J. F. STEVENS

30 Notes on the Quality of Performance of Serum Cholesterol Assays September 1973 s. S. BROWN 